\title{
A response to Annette Gough and Jesse Bazzul. Subverting subjectivity: an anti-neoliberal reformulation of science education for life
}

\author{
Ralph Levinson ${ }^{1}$
}

Received: 16 January 2017/ Accepted: 9 May 2017/Published online: 16 November 2017

(C) The Author(s) 2017. This article is an open access publication

\begin{abstract}
In responding to Jesse Bazzul's and Annette Gough's articles I maintain that contemporary positivist science curricula cannot address the urgent issues of sustainability and biopower that confront us. Drawing on the writings and interpretations of Emmanuel Levinas I argue that contemplating the meaning of responsibility to the Other is a radically subversive activity and a means of moving from the neoliberal dominance of science education towards a science one steeped in social justice.
\end{abstract}

Keywords Pedagogy $\cdot$ Curriculum $\cdot$ Levinas $\cdot$ Responsibility for the Other $\cdot$ Social Justice

Guest editors: L. Carter, M. Weinstein, L. Bencze.

This manuscript is part of the special issue "Biopolitics and Science Education".

This review essay addresses issues raised in Jesse Bazzul's paper entitled Biopolitics and the 'subject' of labor in science education. doi:10.1007/s11422-017-9840-2 and Annette Gough's paper entitled Searching for a crack to let environment light in: ecological biopolitics and education for sustainable development discourses. doi:10.1007/s11422-017-9839-8.

$\triangle$ Ralph Levinson

r.levinson@ucl.ac.uk

1 Institute of Education, University College London, London, UK 
In Charles Dickens' novel, Dombey and Son, the wondering child Dombey, wise beyond his years, addresses his father, the glacial capitalist:

Papa! What's money?

For the senior Dombey, preoccupied with the flow of money for his huge prosperity every moment of his waking life, the question appears incomprehensible. This remarkably simple question resonated with me when reading Jesse Bazzul's and Annette Gough's accounts of biopolitics in relation to science education. The contemporary question to those concerned with science pedagogy and science education policy is now: 'What's life?' And the response is equally complex and disconcerting, not least because life in terms of biopower is used in different ways with different emphases and meanings (Birch and Tyfield 2013). At the height of the Industrial Revolution, and the mass production of iron for the building of the railways - the period recounted in Dombey and Son-life, at least for people like Dombey Senior, was the undifferentiated resource or capital, in the form of wage labour, which generated goods and profits, i.e. surplus value. In the first part of the twentieth century, Charlie Chaplin in the film Modern Times ingeniously demonstrated how far the body had transformed itself into a machine for similar purposes. Today, the self-conscious object of the flow of capital has become life itself. While both articles take their starting off point from biopolitics my response draws on a different theoretical framework, hopefully to illuminate particular aspects I see as both strengths and challenges in these two articles.

\section{Disturbances}

Both articles in their distinctive ways, reveal insights into the problems of science texts and science school discourse more generally (Bazzul) and the educational discourse around environmental education or ESD (Gough). On reflection I encountered ripples of disturbance while I read the articles_-which is to their credit—and it is those disturbances which I want to discuss here.

A thought on 'disturbance'. I have just finished reading Anna Lowenhaupt Tsing's book, The mushroom at the end of the world (2015). The book is about the network of social, economic, biological and cultural relations that link the mycelia (in themselves a bionetwork) of the matsutake mushroom in the worn out forests of Oregon, through assemblages: the forest pickers (mainly from east and south east Asia), the nematode worms that infest the trees which provide undergrowth for the matsutake, and the supply lines that bring matsutake as a delicacy for the Japanese market. It is the well-established supply lines that provide capital growth which are known about rather than the intricacy of production of a complex eco-network inclusive of the pickers. It is the biovalue, the product of sun, carbon dioxide and water, uncontrolled by capitalism, which yet feeds into capitalist commodification. The disturbances Tsing points to are those of eco-systems which provide the possibilities for matsutake harvesting as well as the sites of resistance around what she terms 'pericapitalism'.

My thought on this is that no system, however oppressive, is free from disturbance. One critique from Tsing of Michael Hardt and Antonio Negri is their conception of the 'uniformity of capitalism's hold on the world' (p. 65). Annette Gough, quoting Leonard Cohen, is that there are always interstices that let the light in.

Annette Gough's analysis of the unsatisfactory relationship in the Australian curriculum between science education and environmental sustainability reflects a wider problem in other curricula but also raises questions that are both ethical and political. Many articles in the main environmental journals focus on knowledge as a means of improving attitudes 
and/or individual cognition towards the environment that steer clear of any socio-political critique (e.g. Shepardson, Choi, Niyogi, Charusombat 2011; Fančovičová and Prokop 2011). The broad equation to correct misconceived understandings of lay people and school students is: Accurate science knowledge corrects misconceptions therefore leads to better decision-making.

The Vision I (Roberts 2007) notion of scientific literacy present in U.K., U.S. and Australian curricula which feed into methodologies of performance measurements, such as attitudes and cognition, is inadequate as a tool for any kind of critique or action because of its empiricist and positivist foundations. Even in relatively benign education systems reforms to these curricula would be difficult enough but in neoliberal-dominated discourses of performativity (Ball 2013) and presentism (Hargreaves 2010) such critical formulations are almost impossible. Gough (2015) has demonstrated the insidious way in which science education through the neoliberal formulation of STEM education becomes socialised into Third Way functionalism (Giddens 2008). A solution, unlikely perhaps but the chink that can let in the light, and one alluded to by Jesse Bazzul, is that science education itself becomes a source of critique.

\section{Possibilities through science education}

Michalinos Zembylas (2006) asks the question implicit in both Bazzul's and Gough's analysis: "why the institutionalization of environmental education has subverted its potential as a transformative educational practice and how we might need to find ways to unite social and ecological perspectives' (p. 671). To do this is to expose the dominant positivist underpinning of contemporary science education. The reason why the science curriculum cannot match the Australian curriculum's Sustainability organising ideas is that it is not fit for purpose. The laws and theories that are the staple of school science describe closed systems in all their regularity and can bear no relation to the complexity of the real world (Bhaskar 2011). Its underlying empiricism not only privileges the descriptive over the normative, it refuses any conflation of scientific research and discovery with broader values of justice. A letter to the U.K. School Science Review trenchantly exposes this thinking.

...a much more fundamental misconception, namely that science education has the right and the ability to address the moral and ethical dilemmas created by scientific advances. In my view this is a fallacy. Science is a discipline concerned exclusively with the reliability that can be attributed to factual ('is') statements as a result of empirical investigation. It is widely recognised that 'is' statements in science cannot be turned into the 'ought' statements of moral discourse. For example, science can fairly accurately judge the consequences of bringing together a number of subcritical masses of U235 above a densely populated geographical area. It can say absolutely nothing, however, about whether such an action would be right or wrong. The answer to the latter question lies outside the domain of science, but within the remit of a moral discourse. The domains of scientific and moral discourse are fundamentally different; they have different core concepts (space, time, energy and good, right, ought), different procedural ground rules and different tests for truth. For example, to apply science's empirical test for truth within the moral domain would turn morality into pragmatism. (Hall 1999). 
And that any kind of meaningful discussion about people's abilities to ask questions about the conditions of their existence depends solely on technoscientific expertise.

$\ldots$ in the absence of a thorough grasp of science and a clear understanding of its importance in the context of a particular debate, any discussion will quickly boil down to rhetorical posturing or simply confusion. Asking teenagers to make up their minds about anything is pretty daunting. But if you try to ask them to decide if we need to replace the UK's nuclear powers stations, you are far more likely to get the obvious question: "Sir, what is nuclear power?" (Perks 2006, pp. 17-18).

Besides the practice that 'Sir' is instructing about nuclear power, the problem stated by David Perks simply attacks the notion of discussion without canonical scientific knowledge. It is in no way fitted out to state how that knowledge of nuclear power might be able to provide any kind of solution to the questions asked by 'teenagers'.

When I stated the 'complexity of the real world' I was using the adjective 'real' because I take Roy Bhaskar's view (2011) that both the natural worlds and the social worlds (including the world of science education) have an ontological although fallible reality where knowledge of them is mediated by human consciousness, that is, an epistemological relativism. Covering Laws and principles conveying regularities are insufficient to reveal the complex mechanisms behind phenomena as they occur in open conditions. Instead they are governed by 'causal powers' which are contextually situated. So, Bhaskar identified three layers of reality: the empirical, the actual, and the causal. Taking the example of a medical diagnosis, the empirical is the experience of the patient's suffering or feeling, the actual is the symptom and the causal is the mechanism which relates the symptom to the particular suffering. In terms of science education questions about social justice have a different aspect: rather than delimit questions between the science of nuclear power and its effect on the planet, a critical realist approach would be to ask, given our knowledge of nuclear power, what understanding do we need about its potentially devastating effect on all forms of life, of which knowledge of critical masses and half-lives would form a small part. Or, given the repeated damage to the environment understood through our knowledge of climate change what are the political and social causal powers that fail to staunch these effects and what can we do to mitigate these errors? These are questions which not only make any link between our understanding of science and environmental change critical in a way that positivism cannot attain but also allows interrogation of the nature of science education itself, i.e. what are the obstacles that prevent teachers of science education helping students to reflect and act on what it means and entails to be a human on a sustainable planet. This would involve a critique of sustainability.

My emphasis here would be both on the nature of pedagogy because curriculum change is inert without related pedagogies, and pedagogy presupposes a supportive curriculum framework. If there is to be a shift towards a more eco-centric and post-humanist approach then such a shift has to be consistent with an ethical underpinning to pedagogy; moreover an ethics preceding ontology (Derrida 1999). I am thinking here of the problem of common classroom practice: a teacher plans a lesson with specific learning objectives. The students demonstrate they have attained those objectives. What is taking place here is an imposition of subjectivity, however gently transmitted, the students are objectified and relay what the teacher wants them to learn. I should qualify that this subjectivity is not necessarily what the teacher thinks but what school systems advocate that students need to learn, it is intrinsically instrumentalist and technicist even beyond the present STEM layering. There is an equivalence here with anthropocentric views of the environment: what humans think is good for the environment in terms of their own purposes. What does it then mean to 
apprehend the environment in its totality as an end in itself rather than as a resource for human betterment? In interrogating this problem I draw on the work of Emmanuel Levinas (1989) and those who have interpreted him.

\section{Developing a sense of connectedness}

I came upon Levinas having been intrigued — and disturbed in my own presuppositionswhen observing a remarkable pre-service biology teacher. The topic of the lesson she was teaching was ecological interdependence. She had made some beautiful masks of plants and animals and suggested to the students that through wearing the masks they try and inhabit the world of the frog, water lily, pondweed, tench, etc. (This was not the same as asking students to act out as being a member of another species but simply to reflect on their world). Throughout the lesson the teacher said little but listened very attentively to what the 12-13 year olds said. As the lesson moved on the students tended to move away from their own subjective responses and began to see interconnections from a completely different perspective which brought them to reflect on their responsibilities to the environment. What facilitated this transformation was the trust the pupils had in the teacher's unstated but deep knowledge, and importantly in her refusal to impose her own viewpoint but to expose herself as ignorant and, with the students, coming to a deeper understanding of interdependence. That this particular young woman was the most knowledgeable preservice teacher I had come across paradoxically helped her in 'being ignorant'. And with this her non-presumptiveness (Levinson 2017), her openness to learning and accepting the students as fellow teachers.

While much of educational discourse is concerned either with the individual as learning subject, Levinas is primarily concerned with how the subject becomes confronting the Other. Ethics emerges through an acceptance of responsibility for the Other. Levinas was primarily concerned with the human Other (and his phraseology is gendered and rather conservative) but his ideas can be formulated in considering the non-human Other including the abiotic Other (Blades 2006).

The difficulty here in the Levinasian concept of ethics is that ethics is no longer about utilitarianism, deontology or rights and responsibilities, or other programmatic forms of reasoning, but an acceptance of an Other which helps the subject come into being. If this responsibility to an unnamed other precedes the subject themselves how can we 'think about the non-representable conditions of ethical subjectivity in ways that might inform our practical orientation to the world'? (Todd 2003, p. 2). But it is precisely this nonrepresentability that is at the heart of learning and responsibility; we become subjects by accepting an unconditional responsibility towards the Other. I was reminded about this passivity in learning when struggling with its meaning in the context of the paradigmatic 'active learning' which is usually predicated in opposition to students passively receiving information from the instructor (Prince 2004). Sungwon Hwang and Wolff-Michael Roth (2009) point out the paradox of institutionalised learning:

... if we already knew the thing we were supposed to learn, we would no longer need to learn it.' (p. 59). Resolving the paradox lies in the fact that 'both the intention and the learned object give themselves to us, individuals who play the welcoming hosts of (or are hostage to) what we had not intended. (p. 59). 
Learning is always risky in this 'passive' sense because the student might learn something that the teacher did not intend-something which objectives-led curricula try to staunch.

I do not want to appropriate Levinas's writing to make this and subsequent points about pedagogy and relations to the environment. Levinas comes from a Talmudic, French/ Central European phenomenological tradition that can sometimes seem opaque and difficult to those, like me, not accustomed fully to that tradition, and his interpreters are well aware of the problem of applying his ideas to education, partly because his writing is so antithetical to Enlightenment rationalism, not to mention contemporary neoliberal norms. In that sense his writings and those of his interpreters are illuminating, and more important, 'disturbing' contemporary thinking about education and about science education in particular.

The subject comes into being through responsibility towards the other, addressed by the other, not ontological consciousnesses or egos. This address is very much about vulnerability, the willingness to be addressed, to be open to trauma, uncertainty, abandonment of shelter (Levinas 1994). This addressivity, however, is a repudiation of sameness, the need for seeing others in one's own terms. Ann Chinnery (2000) relates how people who harboured those suffering from cruelty and oppression talked about their deeds in terms of seeing others within a framework of a common humanity. But 'common humanity' implies a responsibility that only extends to those with whom we have some commonality or sameness, that humans are similar in some essential way. It is the openness to the Other, that which is non-recognisable and non-categorisable that I see emerging from Levinas's writing

So, I see a relation between the pre-service teacher, who was refusing to actively teach but being open to the students and their shift from instrumentality towards Nature and a questioning of their own motives, that they live in a world of 'complete connectedness, where the call of the Other necessarily includes the call of the non-human Other' (Blades 2006, p. 655). This begins to address this 'new transversal alliance across species and among posthuman subjects' (Gough citing Braidotti 2013, p. 103).

What is crucial is not to see Levinasian thinking as some kind of technique. Nor is it a sophisticated version of New Ageism. On the contrary its political subversiveness lies in its complete abnegation of the neoliberal programme, a refusal to engage with it on its own terms but a means of asking foundational questions about connectedness which go beyond the human species and indeed living things. This is where a truly subversive science education can provide a critique highlighting the causal powers which explain the symptoms distorting contemporary practices with its supporting institutions and ideologies. Blades' (2006) reformulation of STSE, for example, removes science from the centre of the epistemic concentric circles, with 'environment' on the periphery - the unidirectional flow of knowledge of Vision I-and placing the Other as Environment in the centre, i.e. E-STS.

A recognition of what it is to be 'hailed' in Althusserian terms is therefore a start. Jesse Bazzul's approach through microanalyses of practice in the classroom is a means of identifying those causal powers that maintain the dominance of a certain type of science discourse. But I am troubled about where this resistance from students might come from through recognition in re-production. 'When are we going to do real science?' is a question so many teachers of science will recognise while trying to encourage young people to look at the world in a different way. The common question both within orthodox and unorthodox science lessons is 'Why are we doing this?' I am less hopeful that students will come to recognise a collaborative, community-oriented science as an improved science because it still leaves open the question of power relations between teacher and taught: how should students move from one frame of being hailed to another? This is where I feel 
the thinking about education that Levinas has prompted can provide a fruitful resource for discussion and action.

Open Access This article is distributed under the terms of the Creative Commons Attribution 4.0 International License (http://creativecommons.org/licenses/by/4.0/), which permits unrestricted use, distribution, and reproduction in any medium, provided you give appropriate credit to the original author(s) and the source, provide a link to the Creative Commons license, and indicate if changes were made.

\section{References}

Ball, S. J. (2013). The education debate (2nd ed.). Bristol: The Policy Press.

Bhaskar, R. (2011). Reclaiming reality. Abingdon: Routledge. doi:10.4324/9780203843314.

Birch, K., \& Tyfield, D. (2013). Theorizing the bioeconomy: Biovalue, biocapital, bioeconomics or... what? Science, Technology and Human Values, 38, 299-327. doi:10.1177/0162243912442398.

Blades, D. W. (2006). Levinas and an ethics for science education. Educational Philosophy and Theory, 38, 647-664. doi:10.1111/j.1469-5812.2006.00217.x.

Chinnery, A. (2000). Levinas and ethical agency: Toward a reconsideration of moral education. Philosophy of Education, 2000, 67-74.

Derrida, J. (1999). Adieu to Emmanuel Levinas (P.A. Brault and M. Naas, trans.). Stanford: Stanford University Press.

Fančovičová, J., \& Prokop, P. (2011). Plants have a chance: Outdoor educational programmes alter students' knowledge and attitudes towards plants. Environmental Education Research, 17, 537-551. doi:10. 1080/13504622.2010.545874.

Giddens, A. (2008). The third way: The renewal of social democracy. Cambridge: Polity Press.

Gough, A. (2015). STEM policy and science education: Scientistic curriculum and sociopolitical silences. Cultural Studies of Science Education, 10, 445-458. doi:10.1007/s11422-014-9590-3.

Hall, E. (1999). Science education and social responsibility. School Science Review, 81, 14-16.

Hargreaves, A. (2010). Presentism, individualism, and conservatism: The legacy of Dan Lortie's schoolteacher: A sociological study. Curriculum Inquiry, 40, 143-154. doi:10.1111/j.1467-873X.2009.00472.x.

Hwang, S., \& Roth, W.-M. (2009). Language and experience of self in science and transnational migration. In W.-M. Roth (Ed.), Science education from people for people (pp. 54-69). London: Routledge.

Levinas, E. (1989). The Levinas reader. Oxford: Basil Blackwell.

Levinas, E. (1994). Otherwise than being or beyond essence (trans. by Alphonso Lingis). Dordrecht: Kluwer.

Levinson, R. (2017). I know what I want to teach but how can I know what they are going to learn? In L. Bryan, \& K. Tobin (Eds.), Critical issues and bold visions for science education: The road ahead (pp. $\mathrm{xx}-\mathrm{xx}$ ). Rotterdam: Sense Publishers.

Perks, D. (2006). What is science education for? In T. Gilland (Ed.), What is science education for? (pp. 9-33). London: Academy of Ideas.

Prince, M. (2004). Does active learning work? A review of the research. Journal of Engineering Education, 93(3), 223-231. doi:10.1002/j.2168-9830.2004.tb00809.x.

Roberts, D. A. (2007). Scientific literacy/science literacy. In S. K. Abell \& N. G. Lederman (Eds.), Handbook of research on science education (pp. 729-780). Mahwah: Lawrence Erlbaum.

Shepardson, D. P., Choi, S., Niyogi, D., \& Charusombat, U. (2011). Seventh grade students' mental models of the greenhouse effect. Environmental Education Research, 17, 1-17. doi:10.1080/ 13504620903564549 .

Todd, S. (2003). Introduction: Levinas and education: The question of implication. Studies in Philosophy and Education, 22, 1-4.

Tsing, A. L. (2015). The mushroom at the end of the world. Princeton, NJ: Princeton University Press. doi:10.1515/9781400873548.

Zembylas, M. (2006). Science education as emancipatory: The case of Roy Bhaskar's philosophy of metareality. Educational Philosophy and Theory, 38, 665-676. doi:10.1111/j.1469-5812.2006.00218.x.

Ralph Levinson is Reader in Education at University College London Institute of Education. For 12 years he taught in secondary schools in London. His research interests are socio-political aspects of science and technology, creativity through science, chemistry education and pedagogy. 